\title{
Distribution, habitat use, and implications for the conservation of the globally threatened Azure-rumped Tanager Tangara cabanisi in Guatemala
}

\author{
KNUT EISERMANN, SUSANNE ARBEITER, GERARDO LÓPEZ, CLAUDIA \\ AVENDAÑO and JOSUÉ DE LEÓN LUX
}

\section{Summary}

The Azure-rumped Tanager Tangara cabanisi is a globally threatened species restricted to the Pacific slope mountains of western Guatemala and Chiapas, Mexico. We studied the habitat use of this tanager on the southern slope of Atitlán volcano, department Suchitepéquez, Guatemala, applying distance sampling along transects in humid broadleaf forest and coffee plantations. The tanager was recorded in both habitat types, but encounter rates were significantly greater in broadleaf forest. The estimated density of tanagers in forest at 1,400-1,900 $\mathrm{m}$ was $33-93$ birds $\mathrm{km}^{-2}$. Tanagers were recorded mainly in the upper vegetation strata of forest and shade coffee plantations. In coffee plantations tanagers used mainly tall solitary trees or the canopy of shade trees, which were dominated by Inga spp. The number of observations of feeding tanagers in Ficus aurea (Moraceae) indicated a high importance of this food source. The density of $F$. aurea trees and the encounter rate of tanagers were positively correlated. From 1987 to 2009 tanagers have been recorded at nine topographic units and a total of 16 sites in Guatemala, in the departments of San Marcos, Quetzaltenango, Sololá, Suchitepéquez, and Chimaltenango. We analysed the available habitat for tanagers in the potential area of distribution $\left(1,170 \mathrm{~km}^{2}\right)$, ranging from 900 to $1,900 \mathrm{~m}$ altitude and from the Mexican border in the West to the municipality of Pochuta in the East. Broadleaf forest covers $250 \mathrm{~km}^{2}$ or $21 \%$ of the potential area of distribution, and coffee plantations cover $800 \mathrm{~km}^{2}$ or $68 \%$. Assuming that population density in prime habitat throughout the potential distribution range is similar to our study area at Atitlán volcano, total tanager population in Guatemala is estimated to be $8,250-23,250$ birds. Our findings support the maintenance of the IUCN Red List status of Endangered EN BIa+b(ii,iii,v). To enhance the available habitat for Azure-rumped Tanager, we propose alterations in the shade management of coffee plantations, supported by incentives and certification programmes.

\section{Resumen}

La Tángara de Cabanis Tangara cabanisi es una especie globalmente amenazada que está restringida a las montañas de la vertiente Pacífica en el oeste de Guatemala y a Chiapas, México. Estudiamos el uso de hábitat de esta tángara en la vertiente sur del volcán Atitlán, departamento de Suchitepéquez, Guatemala, aplicando el método de "distance sampling" a lo largo de transectos en bosque latifoliado húmedo y en plantaciones de café. Las Tángaras de Cabanis fueron registradas en ambos tipos de hábitat, pero el índice de detección fue significativamente mayor en bosque latifoliado. La densidad estimada de la poblacón de la Tángara de Cabanis en bosque de $1,400-1,900 \mathrm{~m}$ fue de $33-93$ individuos $\mathrm{km}^{-2}$. Las tángaras fueron registradas principalmente en 
el estrato superior de vegetación. En plantaciones de café las tángaras usaron principalmente árboles altos solitarios o el dosel de árboles de sombra, que fue dominado por Inga spp. El número de observaciones de tángaras alimentándose en Ficus aurea (Moraceae) indicó una alta importancia de este recurso alimenticio. La densidad de árboles de F. aurea y el índice de detección de Tángara de Cabanis estuvieron positivamente correlacionadas. De 1987 a 2009 la Tángara de Cabanis ha sido registrada en nueve unidades topográficas y un total de 16 lugares en Guatemala, en los departamentos de San Marcos, Quetzaltenango, Sololá, Suchitepéquez y Chimaltenango. Analizamos el hábitat disponible para las Tángaras de Cabanis en su área potencial de distribución $\left(1,170 \mathrm{~km}^{2}\right)$, cubriendo desde 900 hasta $1,900 \mathrm{~m}$ de altitud, y desde la frontera con México al oeste hasta el municipio de Pochuta en el este. Los bosques latifoliados cubren $250 \mathrm{~km}^{2}$ ó $21 \%$ de esta área y las plantaciones de café cubren $800 \mathrm{~km}^{2}$ ó $68 \%$. Asumiendo una densidad de Tángaras de Cabanis similar al área de estudio en volcán Atitlán en todos los bosques latifoliados, la población total en Guatemala se estima en 8,250-23,250 individuos. La información de uso de hábitat y extensión de hábitat apropiado justifica mantener el estado de Amenazada EN Bıa+b(ii,iii,v) en la Lista Roja de UICN. Para aumentar el hábitat disponible para la Tángara de Cabanis proponemos alteraciones en el manejo de sombra de plantaciones de café, apoyado por programas de incentivos y certificaciones.

\section{Introduction}

The Azure-rumped Tanager Tangara cabanisi is a species of restricted range occurring in the Pacific slope mountains of Guatemala and Chiapas, Mexico, where it has been reported from a narrow altitudinal belt between 1,000 and 1,700 m (Parker et al. 1976, Hilty and Simon 1977, Vannini 1989, Heath and Long 1991, Cooper 2003, Tenez 2005, Valdez et al. 1999, Eisermann and Avendaño 2006, 2007a). South of Lake Atitlán it was first reported in the Pachuj Reserve in 1999, later also in the Los Andes Reserve in 2000 (Eisermann and Avendaño 2006), and in the Los Tarrales Reserve in 2004 (Jones 2004).

Information on the ecology of the Azure-rumped Tanager originates mainly from observations in the Sierra Madre de Chiapas. Brodkorb (1939) collected the first specimen there in cloud forest, and Heath and Long (1991) provided information on habitat preferences, where by this time it had only been recorded in the interior and on the edge of broadleaf forests. They reported Ficus cookii as the dominant tree species in Azure-rumped Tanager habitat in the El Triunfo Biosphere Reserve. Ficus cookii belongs to the F. aurea species complex (Berg 2007). Heath and Long (1991) estimated suitable tanager habitat as $1,125 \mathrm{~km}^{2}$ in Chiapas. The species is considered 'Endangered' at a global level because of its small area of distribution and loss of habitat, primarily through the replacement of broadleaf forests by coffee plantations (Collar et al. 1992, BirdLife International 2008).

The Guatemalan Pacific slope highlands are one of the country's main areas for coffee cultivation. Recently, the Azure-rumped Tanager has been observed in both habitat types, humid broadleaf forest and coffee plantations (Dietsch 2000, BirdLife International 2008). For Guatemala, the extent of suitable habitat has not yet been quantified. Here we quantify the use by the species of forest and coffee plantations, and then analyse the extent of suitable habitat throughout Guatemala. Because we observed feeding tanagers mainly in Ficus aurea trees, we furthermore determine the correlation of the population density of this tree with the abundance of Azure-rumped Tanager. We provide implications for conservation of this species.

\section{Methods}

\section{Study area}

The Azure-rumped Tanager's known area of distribution in the western Pacific slope mountains of Guatemala is characterised by a chain of several major volcanoes. The altitudinal belt between 
1,000 and $1,900 \mathrm{~m}$ is shaped by very pronounced slopes of $>30 \%$. The mean annual rainfall amounts to $2,000-4,600 \mathrm{~mm}$, but can locally reach a maximum of $6,000 \mathrm{~mm}$ annually. The wet season extends from April to November with a mean monthly precipitation of $150-800 \mathrm{~mm}$, and the dry season from December to March with mean monthly precipitation of 5-150 mm (MAGA 2002).

Annual mean minimum temperature is $15^{\circ} \mathrm{C}$; annual mean maximum is $25^{\circ} \mathrm{C}$ (MAGA 2002). The natural climax vegetation in this area is humid evergreen broadleaf forest, with broadleafconifer forest in higher and less humid areas. Much of the forest $<_{1,600} \mathrm{~m}$ altitude has been replaced by coffee plantations and other agricultural crops in the 19th century.

To determine habitat use by Azure-rumped Tanagers, we conducted counts along trails in the neighbouring private nature reserves Los Tarrales, Los Andes, and San Jerónimo Miramar, department Suchitepéquez, where the species had been recorded previously (Eisermann and Avendaño 2007a). The rectangle encompassing all trails had a size of 1,950 ha (geographic

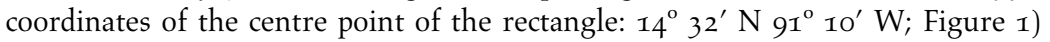

\section{Landcover}

For land cover analyses in the potential area of distribution of Azure-rumped Tanager in Guatemala we used the most recent national landcover mapping at a scale of 1:50,000, based on Landsat images and ground truthing with local experts (MAGA 2006). Land cover in the study area on Atitlán volcano was mapped based on orthoimages with a ground resolution of $0.4 \mathrm{~m}$, based on aerial photographs from December 2005 (MAGA 2010) and ground-truthed field observation in 2008. We mapped Ficus aurea trees within a total strip width of $120 \mathrm{~m}$ along all transects from orthoimages with some ground-truthing. Software ESRI ArcView GIS 3.2 was used for all spatial analyses.

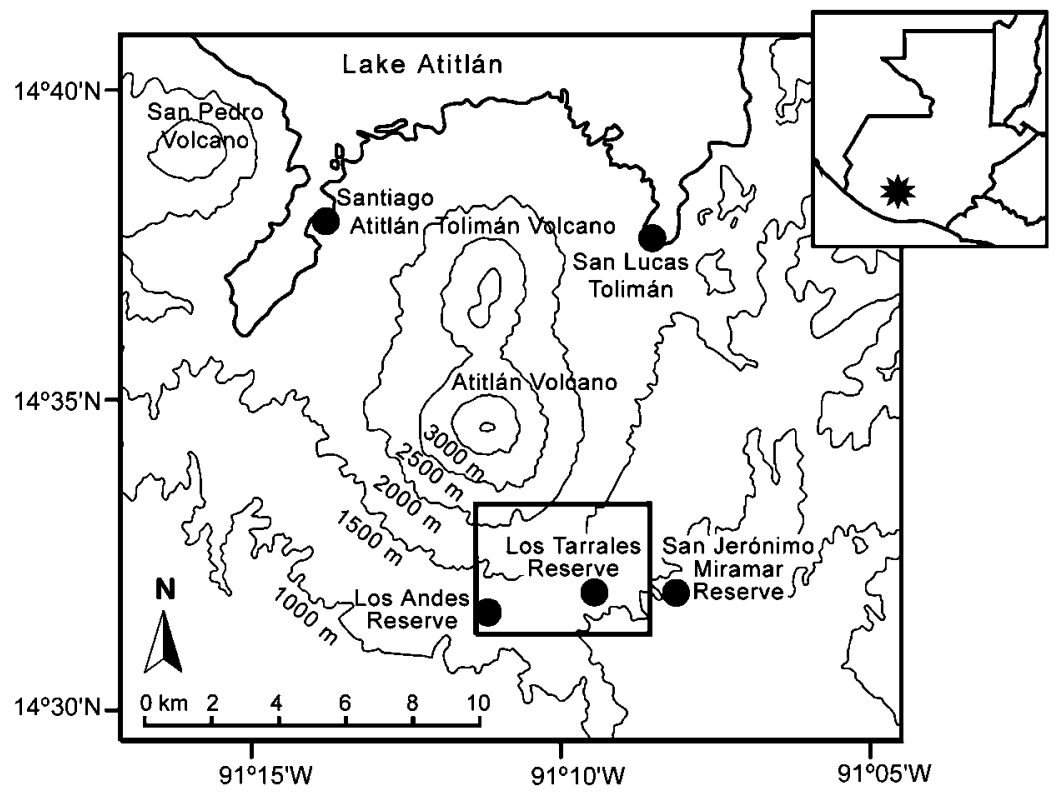

Figure 1. Study area at Atitlán volcano. The inset map shows the location of the study area in Guatemala. 


\section{Vegetation structure}

We produced foliage-height profiles modified after Blondel and Cuvillier (1977) by determining vegetation density in 20 strata. We used a $9 \mathrm{~m}$ long telescopic pole, which was marked from 0.5 to $9 \mathrm{~m}$, and a laser rangefinder (Nikon ProStaff Laser 440). Along 15 of 21 transects, four evenly spaced sites were defined using a handheld GPS device. At each site, foliage coverage was measured at six points at the perpendicular distance of 10, 20, and $30 \mathrm{~m}$ on both sites of the transect. At each point the telescopic pole was positioned vertically, noting whether plants touched the pole on marks at $0.5,1,1.5,2,2.5,3,4,5,6,7,8$, and $9 \mathrm{~m}$. Above this height, we used the laser rangefinder to determine whether plants touched at the imaginary elongation of the pole at $10,12,15,20,25$, 30,35 , and $40 \mathrm{~m}$. All measurements were taken by the same observer (KE). The percentage of presence of plant parts was used as vegetation density index.

\section{Bird surveys}

Counts of Azure-rumped Tanagers were conducted along 21 line transects in forest and in coffee plantations (Table 1 , Figure $S_{1}$, in online supplementary material) applying the distance sampling method (Buckland et al. 2001). Because habitat distribution was patchy, none of the transects in coffee plantations was farther than $150 \mathrm{~m}$ away from the nearest forest edge. After familiarisation with the different vocalisations of the tanagers (Eisermann et al. 2011), two observers (SA, GL) walked along the transect at an average speed of $1 \mathrm{~km} \mathrm{~h}^{-1}$ between o6h15 and 1ohoo (sometimes until ${ }_{15} \mathrm{~h}_{30}$ ) under favourable weather conditions (i.e. without rain and no or low wind [wind speed not more than 3 on the Beaufort scale]). All tanagers heard and seen were recorded, together with the following data: number of individuals per flock, perpendicular distance from the

Table 1. Number of Azure-rumped Tanagers recorded at each transect line with an effective strip width of $60 \mathrm{~m}$.

\begin{tabular}{|c|c|c|c|c|c|}
\hline $\begin{array}{l}\text { Transect and } \\
\text { habitat* }^{*}\end{array}$ & $\begin{array}{l}\text { Transect } \\
\text { length }(\mathrm{m})\end{array}$ & $\begin{array}{l}\text { Number of } \\
\text { visits }\end{array}$ & $\begin{array}{l}\text { Total } \\
\text { length }(\mathrm{m})\end{array}$ & $\begin{array}{l}\text { Number of } \\
\text { individuals }\end{array}$ & $\begin{array}{l}\text { Number of } \\
\text { individuals / } 100 \mathrm{~m}\end{array}$ \\
\hline Io (fh) & 1,040 & 12 & 12,480 & 55 & 0.44 \\
\hline 20 (fh) & 2,570 & 7 & 19,190 & 90 & 0.47 \\
\hline 22 (fh) & 350 & 7 & 2,450 & 5 & 0.20 \\
\hline 23 (fh) & 610 & 21 & 12,810 & 8 & 0.06 \\
\hline 24 (fh) & 310 & 5 & 1,550 & 5 & 0.32 \\
\hline 26 (fh) & 1,340 & 2 & 2,680 & 11 & 0.41 \\
\hline 27 (fh) & 300 & 2 & 600 & 11 & 1.83 \\
\hline $2(\mathrm{fl})$ & 340 & $I$ & 340 & o & 0.00 \\
\hline $5(\mathrm{fl})$ & 450 & 1 & 450 & o & 0.00 \\
\hline $8(\mathrm{fl})$ & 1,120 & 7 & 7,680 & 1 & 0.01 \\
\hline I6 (fl) & 1,470 & 7 & 10,290 & 7 & 0.07 \\
\hline 17 (fl) & 890 & 6 & 5,340 & o & 0.00 \\
\hline II (ci) & 1,480 & 8 & 11,840 & o & 0.00 \\
\hline 15 (ci) & 520 & 7 & 3,640 & o & 0.00 \\
\hline 21 (ci) & 730 & 7 & 5,110 & o & 0.00 \\
\hline 29 (ci) & 1,220 & 2 & 2,440 & o & 0.00 \\
\hline $13(\mathrm{cn})$ & 1,220 & 9 & 10,980 & 8 & 0.07 \\
\hline $14(\mathrm{cn})$ & 870 & 16 & 10,140 & o & 0.00 \\
\hline $25(\mathrm{cn})$ & 500 & 5 & 2,500 & o & 0.00 \\
\hline $30(\mathrm{cn})$ & 330 & 10 & 3,300 & 2 & 0.06 \\
\hline $31(\mathrm{cn})$ & 240 & 6 & 1,440 & o & 0.00 \\
\hline
\end{tabular}

${ }^{*}$ ci: intensive coffee plantation; $\mathrm{cn}$ : non-intensive coffee plantation; fh: forest at $1,400-1,900 \mathrm{~m}$; fl: forest at 900-1,300 m 
transect (measured with a laser rangefinder), estimated height of birds above ground and height of vegetation at the same point. Geographic coordinates of all records were recorded on the trails using a handheld GPS device (Garmin 6oCSx). When tanagers were observed feeding, food source was noted. Voucher specimens of food plants were deposited in the herbarium BIGU of the School of Biology of San Carlos University, or in the herbarium AGUAT of the Faculty of Agronomy of the San Carlos University, both located in Guatemala City (Table SI). Coincidental observations of Azure-rumped Tanager were recorded together with the geographic coordinates determined with a GPS device.

Available foot trails were used for line transect counts, which were repeated between one and 21 times from 19 June to 8 August 2008. Because data from repeated transect lines are not independent, we pooled data from all repetitions and calculated with the total transect length of all repetitions, as recommended by Buckland et al. (2001). Density was estimated using software Distance 5.0 Release 2 (Thomas et al. 2006).

To compare mean encounter rates between forest and coffee plantations, we truncated data at $30 \mathrm{~m}$. Each transect line was considered a replication unit and differences in mean values where compared with a randomisation test with $\alpha=0.05$ using SsS software (Engel 1998). Means are given together with standard deviation if not otherwise indicated. Geometric Mean Regression (Ricker 1984, Krebs 1999) was applied to analyse the correlation between the distribution of Ficus aurea trees and encounter rate of Azure-rumped Tanagers using SsS software (Engel 1998) with $\alpha=0.05$.

\section{Distribution and population size of Azure-rumped Tanager in Guatemala}

As a basis for derivation of total population size of Azure-rumped Tanagers in Guatemala, we compiled data on the presence of the species in other areas from published references, from our own occasional observations, from data in eBird Guatemala (http://ebird.org/content/guatemala/), and from Christmas Bird Counts on Atitlán volcano (http://www.audubon.org/bird/cbc/hr/index.html). We calculated the total population size for Guatemala assuming that the population density throughout the remaining prime habitat is similar to the density determined at Atitlán volcano.

\section{Results}

\section{Vegetation cover and structure at Atitlán volcano}

The Atitlán volcano is one of the major forest patches in the Guatemalan Pacific slope mountains, although much of the forest below 1,600 $\mathrm{m}$ has been replaced by coffee plantations. All coffee plantations within the study area were shaded monocultures according to a classification by Perfecto et al. (2005), with a shade cover of $10-30 \%$ and $1-5$ species of shade trees. Within the study area we discriminated between intensive and non-intensive coffee plantations, classified by differences in shade coverage and density of coffee shrubs. Vegetation cover within the study area was as follows: broadleaf forest covered 1,411 ha ( $72 \%$ of the study area), intensive coffee plantations 337 ha $(17 \%)$, non-intensive coffee plantations 105 ha $(5 \%)$, other intensive plantations (ponytail Beaucarnea recurvata, tea Camellia sinensis and others; complete nomenclature of all plant names is indicated in Table $\left.\mathrm{S}_{1}\right) 59$ ha (3\%), scrub 12 ha (1\%), and orchard-like settlements 14 ha (I\%) (Figure SI).

Foliage-height profiles show that broadleaf forest along transects was up to $40 \mathrm{~m}$ high, with a dense understorey of herbs and shrubs (including palms) and a dense canopy (Figure 2a,b). Vines were included in the class of shrubs, which were more abundant in forest at 900-1,300 $\mathrm{m}$ than in high-elevation forest at 1,400-1,900 m. Coverage of Ficus aurea trees in the canopy was higher in high-elevation forest.

Coffee plantations had a shrubby understorey with an open canopy of shade trees (Figure 2c,d). Non-intensive coffee plantations had a low density of coffee shrubs in the understorey, where 

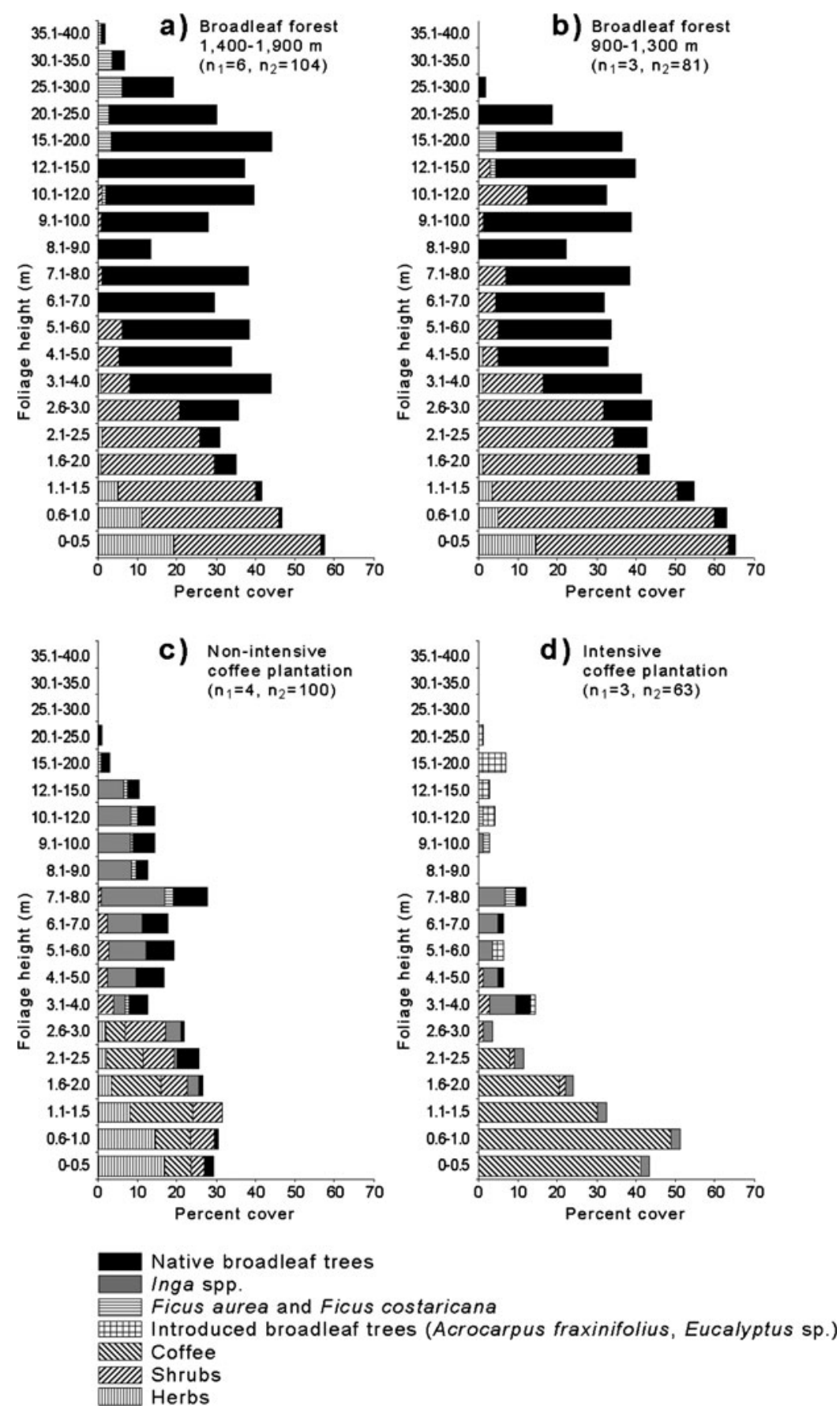

Figure 2. Foliage height profiles of a) broadleaf forest at $1,400-1,900 \mathrm{~m}, \mathrm{~b}$ ) broadleaf forest at 90o$1,300 \mathrm{~m}, \mathrm{c}$ ) non-intensive coffee plantation, and d) intensive coffee plantation. $n_{1}$ indicates the number of transects and $n_{2}$ the number of points where vegetation cover was measured. Percent cover represents the mean percentage of plant touches on a pole in the indicated height classes. 
they compete with native shrubs and herbs. Herbs were absent in intensive coffee plantation because of intensive use of herbicides. The canopy of shade trees in non-intensive plantations was dominated by Inga spp. trees (mainly Inga micheliana, but also I. spuria, I. rodrigueziana, and I. laurina) with a dense cover. Inga trees in intensive plantation were heavily pruned and these plantations also had non-native species of shade trees (Acrocarpus fraxinifolius, Eucalyptus sp.).

\section{Habitat use, density, and abundance of Azure-rumped Tanagers at Atitlán volcano}

Azure-rumped Tanagers were recorded on the south-eastern slope of Atitlán volcano from 860 to $1,900 \mathrm{~m}$ in primary humid broadleaf forest, in coffee plantation, and in edge habitat. A total of 134 observations of Azure-rumped Tanager involving 282 birds were recorded during transect counts between 19 June and 8 August 2008. In the forest interior ( $>30 \mathrm{~m}$ from habitat edge) 92 observations ( 202 birds) were recorded; in forest edge habitat $(<30 \mathrm{~m}$ to forest edge) 21 observations ( 38 birds); in the interior of non-intensive coffee plantations three observations (six birds); in non-intensive coffee plantation edge habitat 11 observations ( 21 birds); and in intensive coffee plantation edge habitat 7 observation ( 15 birds). No tanagers were recorded in the interior of intensive coffee plantations. Because the sample size of tanagers in the interior of coffee plantations is too small to calculate a detection probability in this habitat, we compare encounter rates between habitats. For that we used only data of tanagers observed in the interior $(>30 \mathrm{~m}$ from the edge) of the sampled habitat, and truncated data at $30 \mathrm{~m}$ in order to lower the effect of higher detection probabilities in coffee plantations than in forests. Mean number of individuals recorded per $100 \mathrm{~m}$ of transect with a strip width of $60 \mathrm{~m}$ (Table $\mathrm{I}$ ) was significantly higher in forest (both types of forest pooled) than in coffee plantations (both types of coffee plantations pooled) (randomisation test, differences in means $0.303, P<0.05$, based on 1 , 000 permutations). Mean number of tanagers was also significantly higher in high-elevation forest (tanager's prime habitat) versus non-intensive coffee plantation (randomisation test, differences in means 0.507 , $P<0.05$, based on 792 permutations).

Although tanagers were recorded as low as $860 \mathrm{~m}$ above sea level, mean encounter rate in forests $1,400-1,900 \mathrm{~m}(0.53 \pm 0.59$ birds/100 $\mathrm{m})$ was significantly higher than in forests at $900-$ $1,300 \mathrm{~m}(0.02 \pm 0.03 \mathrm{birds} / 100 \mathrm{~m})$ (permutation test, differences in means $0.517, P<0.05, n=$ 972 permutations), indicating that high-elevation forest is the tanager's main habitat. Sample size in forests at $1,400-1,900 \mathrm{~m}$ was sufficient to model detection probability. Along seven transect lines in forest at 1,400-1,900 m with a total sampling effort of $49.2 \mathrm{~km}, 89$ detections of Azurerumped Tanager were recorded. Data from distance sampling procedure fitted best a hazard-rate distribution, using Akaike's Information Criterion (AIC) for model selection and best goodnessof-fit tested with chi-square test for each interval. A good model fit was achieved with data truncation at $65 \mathrm{~m}$ and classification in five distance intervals (Figure 3). Mean flock size was 2.17 individuals (SE 0.07; 95\% confidence interval: 2.02-2.33). Estimated density of Azure-rumped Tanagers in forest at $1,400-1,900 \mathrm{~m}$ was 26 flocks $\mathrm{km}^{-2}$ (95\% confidence interval: $15-43$ flocks $\mathrm{km}^{-2}$ ) or 56 birds km $\mathrm{km}^{-2}$ (95\% confidence interval: 33-93 birds km${ }^{-2}$ ) from June to August 2009. Thus, population size of Azure-rumped Tanager in the approximately $5 \mathrm{~km}^{2}$ of forest between 1,400 and 1,900 m within the study area at Atitlán volcano is estimated to be $165-465$ individuals.

The largest flock seen during transect counts consisted of five birds. During occasional observations of Azure-rumped Tanager, birds were seen usually in pairs or small groups of 3-4 individuals during the breeding season. After fledging, larger groups were seen. A flock of seven birds was seen on 3 September 2009 (GL pers. obs.), among them were two young birds. At least 14 tanagers were observed on 13 August 2008 (GL pers. obs.) moving in the canopy of a Ficus aurea tree in primary forest, among them were at least five young birds. We never observed Azure-rumped Tanagers in true mixed foraging flocks. On occasions when we recorded them together with other species, for instance with White-winged Tanager Piranga leucoptera on 11 July 2008 (SA and GL pers. obs.) in Los Tarrales, and with Common Bush-tanager Chlorospingus ophthalmicus on 15 August 2009 in the forest reserve of San Rafael Pie de la Cuesta (KE and CA, 


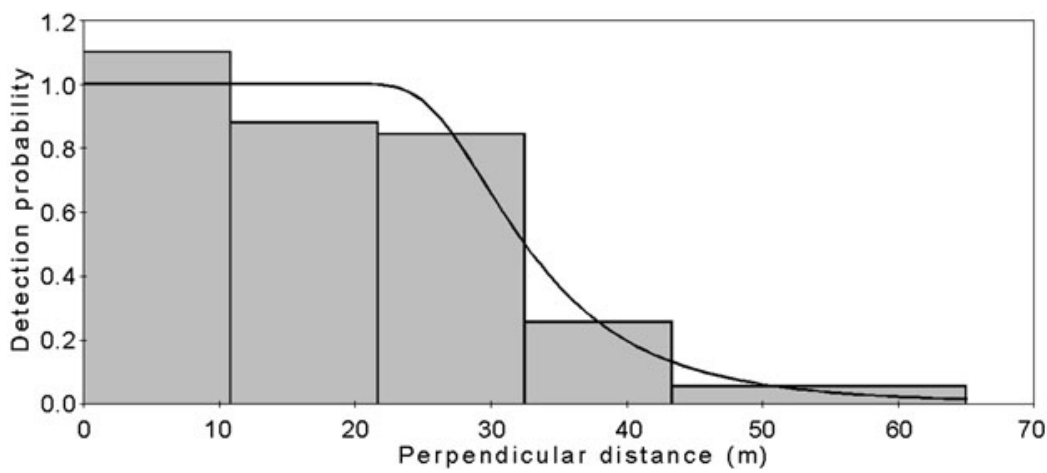

Figure 3. Histogram of the distance data for Azure-rumped Tanagers detected in forest between 1,400 and $1,900 \mathrm{~m}$, and detection function obtained by fitting the hazard-rate model (software Distance 5.0 Release 2) to the data which were truncated at $65 \mathrm{~m}$, and grouped into five distance classes.

pers. obs.), they were apparently together in the same fruit tree by coincidence, and did not move on together.

The height of observed Azure-rumped Tanagers in vegetation was recorded during transect counts for 90 detections in forest and edge, and for 16 detections in coffee plantation and edge. The

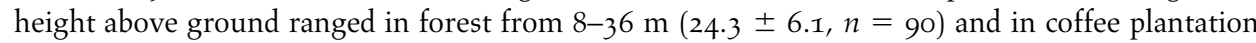
from 8-30 $\mathrm{m}(18.9 \pm 7.2, n=16)$. Tanagers stayed mainly in the upper vegetation strata, mean relative height in vegetation was $83 \% \pm 17(n=90)$ in forests and $83 \% \pm 20(n=16)$ in coffee plantations. In coffee plantations tanagers were recorded mainly in solitary large trees (Ficus aurea and F. costaricana) or in the canopy of shade trees (Inga spp.). Occasionally tanagers were also seen very low in the understorey, foraging on fruiting shrubs in the forest or collecting nest material from coffee shrubs as low as $1 \mathrm{~m}$ above ground.

During transect counts a total of 41 observations of feeding tanagers were recorded, of which 35 were feeding on fruit of the strangler fig Ficus aurea (Moraceae), one on Ficus costaricana, two on Rhamnus discolor (Rhamnaceae), one on Trema micrantha var. strigillosa (Ulmaceae), one in mistletoe Phoradendron heydeanum (Verbanaceae), and one in Perrottetia longistylis (Celastraceae). During occasional observations throughout the tanager's range in Guatemala, the species was seen feeding also on fruit of Miconia sp. (Melastomataceae) (KE and CA pers. obs.), on Cecropia obtusifolia (Cecropiaceae) (KE, JLL, EB pers. obs.), on Chomelia brachypoda (Rubiaceae), on Cestrum sp. (Solanaceae) (KE and CA pers. obs.), and on Urera sp. (Urticaceae) (J. L. Yuxón pers. comm.) (see Table SI for complete nomenclature of all plant names). Tanagers were also seen foraging among inflorescences of Meriana macrophylla (Melastomataceae), probably on invertebrates (KE and CA pers. obs.).

The number of observations of feeding tanagers in Ficus aurea suggests a high importance of that food source. F. aurea is semi-deciduous and the trees are leafless for some weeks in the dry season and identifiable on orthoimages. The density of $F$. aurea trees within a strip width of 120 $\mathrm{m}$ ranged from $\mathrm{o}-2$ trees $\mathrm{ha}^{-1}$ along all forest transects (Table S2). The slope (0.626 $\left.\pm 0.149 \mathrm{SE}\right)$ of the Geometric Mean Regression line comparing density of $F$. aurea trees from Table $\mathrm{S}_{2}$ versus number of Azure-rumped Tanagers per $100 \mathrm{~m}$ of transect from Table $I$ is significantly different from o (Student's t-test, $t=4.21, \mathrm{df}=10, P<0.005$ ), indicating a positive correlation between the abundance of Azure-rumped Tanager and density of F. aurea trees (Figure 4).

\section{Distribution in Guatemala}

The Azure-rumped Tanager has been reported in Guatemala from nine topographic units and a total of 16 sites from 1987 to 2009, located in the departments of San Marcos, Quetzaltenango, 


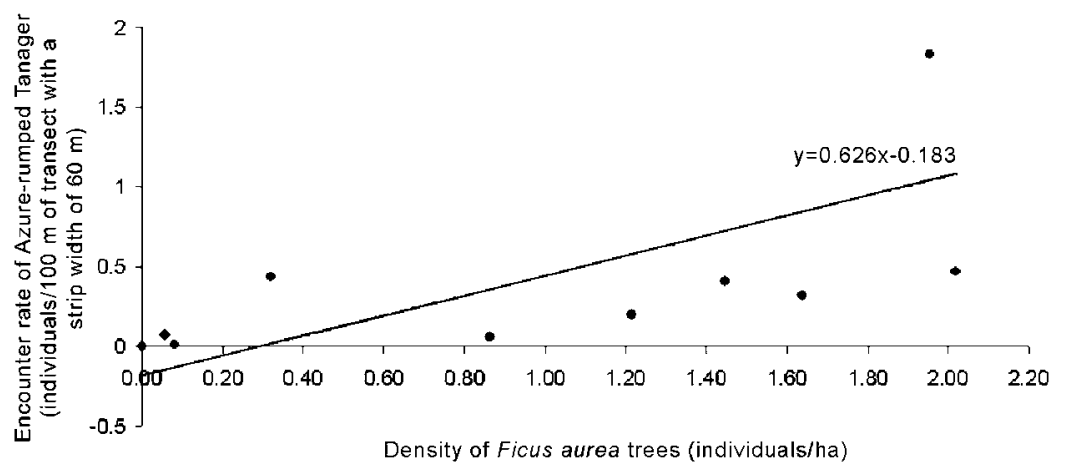

Figure 4. Encounter rate of Azure-rumped Tanagers in relation to the density of Ficus aurea trees. The slope of the geometric mean regression line is significantly different from o (Student's t-test, $t=4.21, \mathrm{df}=10, P<0.005)$.

Sololá, Suchitepéquez, and Chimaltenango (Table $\mathrm{S}_{3}$, Figure 5a). The easternmost record is from Unión Victoria $\left(14^{\circ} 34^{\prime} \mathrm{N} 91^{\circ}{ }^{\circ} 3^{\prime} \mathrm{W}\right)$, former Finca El Salvador, municipality Pochuta, $5 \mathrm{~km}$ northeast of Pochuta. The potential area of distribution of Azure-rumped Tanager in Guatemala can be limited by the upper and lower altitudinal limits of all records, as well as the easternmost record and the Mexican border. This area has a size of $1,170 \mathrm{~km}^{2}$.

From information on habitat use in our study area at Atitlán volcano we derived the coverage of adequate habitat within the potential area of distribution. Based on a nationwide land cover mapping on the scale 1:50,000 (MAGA 2006), broadleaf forest covers approximately $250 \mathrm{~km}^{2}$ or $21 \%$ of the entire potential area of distribution of Azure-rumped Tanager in Guatemala (Figure 5 b). Most of the potential area of distribution is covered by coffee plantations (approximately 800 $\mathrm{km}^{2}$ or $68 \%$ ). Largest forest patches are located south of San Marcos (northern part of the municipalities Tumbador, Nuevo Progreso, and La Reforma), on the southern slope of Lacandón volcano, on the south-eastern slope of Chicabal volcano, on the southern slopes of Santa María, Santo Tomás, and Atitlán volcanoes, and on the southern part of the municipality Santiago Atitlán, and in the valley of the Río Madre Vieja southeast of San Lucas Tolimán (Figure $5 \mathrm{~b}$ ). Assuming that the density of Azure-rumped Tanagers in all broadleaf forests is similar to the value determined in the study area at Atitlán volcano, total population of Azure-rumped Tanagers in Guatemala is estimated to be $8,250-23,250$ birds.

\section{Discussion}

\section{Distribution and conservation status}

The type specimen of Azure-rumped Tanager was collected in Costa Cuca (Cabanis 1866, Sclater 1868; type specimen ZMB 18921 reviewed). In the 19th century, Costa Cuca was not a town or village, but a region of about $1,300 \mathrm{~km}^{2}$, which is today the southern part of the department of Quetzaltenango (Gallini 2009). The type locality has been erroneously attributed to the village Flores Costa Cuca (elevation $500 \mathrm{~m}$ ) in several publications (Heath and Long 1991, Collar et al. 1992). All recent records are from the altitudinal range of $860-1,900 \mathrm{~m}$, which is a narrow belt about $10 \mathrm{~km}$ wide. Therefore the type specimen had most likely been collected in the upper part of the former Costa Cuca area. After the type specimen of Azure-rumped Tanager was collected in the 19th century, only recently have additional localities been reported in the modern department of Quetzaltenango (Heath and Long 1991, Cooper 2003, Eisermann and Avendaño 2006, 2007a). This study documents an expansion of the altitudinal $(860-1,900 \mathrm{~m})$ and longitudinal range (east 

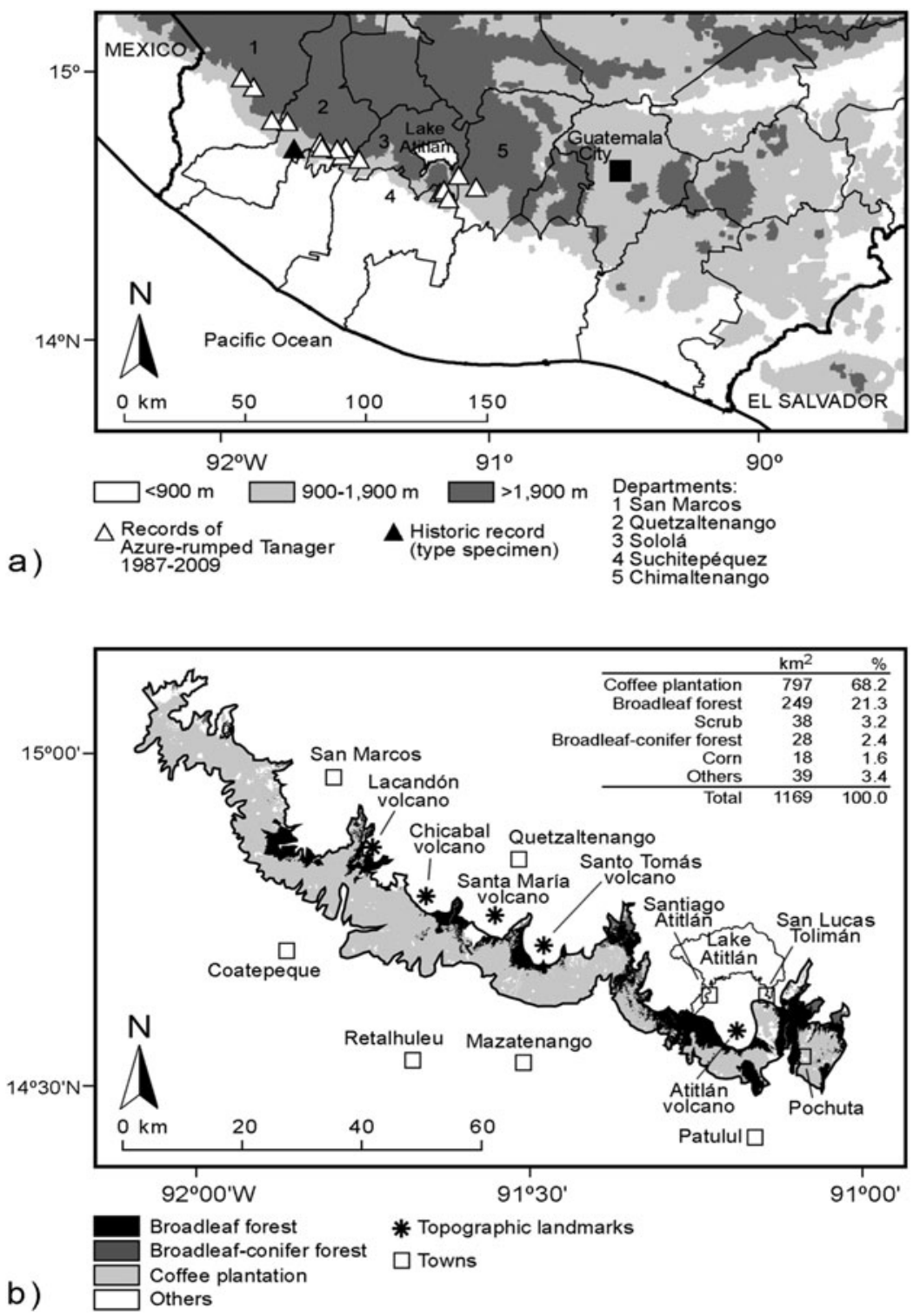

Figure 5. Distribution and habitat availability of Azure-rumped Tanager in Guatemala. a) Locations of all records in Guatemala, altitudinal zones, and department limits. b) Landcover in the potential area of distribution, limited by the Mexican border in the West and the easternmost record, and by contour lines of $900 \mathrm{~m}$ and $1,900 \mathrm{~m}$, representing approximate altitudes of the lowest and highest records.

of the valley of the Nicán river). This species may be expected even further east in Guatemala, such as on the southern slope of Fuego and Agua volcanoes in the department of Sacatepéquez, which is supported by an anecdotal record at Pacaya volcano on 12 April 2010 (Dan Poalillo pers. comm.). 
The Azure-rumped Tanager has been reported previously from humid broadleaf forest and also from coffee plantations (Dietsch 2000, BirdLife International 2008). Our comparison of encounter rates in forest and coffee plantation shows that the species is more abundant in humid broadleaved forest. In addition, most of our records from coffee plantations were within a distance of $30 \mathrm{~m}$ from forest edge. Thus, the Azure-rumped Tanager is primarily a forest bird, which also uses forest edge and adjacent open habitat as do many other tanagers (Isler and Isler 1987).

Most of the prime habitat of Azure-rumped Tanager in Guatemala has been converted to coffee plantations and only $250 \mathrm{~km}^{2}$ of potential habitat remain (Figure $5 \mathrm{~b}$ ). The tanager is fairly common and occurs with a density of $33-93$ birds $\mathrm{km}^{-2}$ on the southern slope of Atitlán volcano. It is also common at other sites such as in the departments of San Marcos (Cooper 2003) and Quetzaltenango (Table $\mathrm{S}_{3}$ ). However, the species is vulnerable to population declines, because most of the suitable habitat is located in a zone especially favourable for agriculture, except for the steepest canyons and mountain slopes. According to recent information on protected areas (CONAP 2009), within the potential area of distribution, only $370 \mathrm{~km}^{2}(32 \%)$ occur within protected areas, and $138 \mathrm{~km}^{2}(55 \%)$ of the remaining broadleaf forest in this area are legally protected (Table $\mathrm{S}_{4}$ ), but none of the reserves is a strictly protected area in IUCN categories I or II (IUCN 1994). Efficient conservation of habitat cannot be guaranteed in the short term in any of the reserves. Although many of the privately protected areas currently are among the best protected preserves in Guatemala, driven by a strong personal interest of owners, national law of protected areas (Decreto 4-89, Congreso de la República de Guatemala) and its rules (Acuerdo Gubernativo 759-90) do not require a long-term commitment of owners for conservation, nor do they require continued conservation from future land owners. Guatemala's state reserves lack adequate management and law enforcement, which makes them vulnerable to illegal invasions followed by an advancing agricultural border, illegal extraction of forest resources and hunting (ParksWatch 2002, 2005, Godoy 2008). The remaining suitable habitat of Azure-rumped Tanager in Chiapas was estimated to be $1,120 \mathrm{~km}^{2}$ in the 1980 (Heath and Long 1991), but rapid human population growth in Chiapas ( $1.6 \%$ annual growth rate from 2000 to 2005; INEGI 2008) combined with an ongoing human pressure on the Sierra Madre de Chiapas (Richter 2000) suggest recent considerable loss of habitat there. The total extent of occurrence in both countries (minimum convex polygon encompassing all sites of occurrence) is less than $2,500 \mathrm{~km}^{2}$. We expect a further decline of the extent of suitable habitat because of continued growth of human population, which in Guatemala is expected to double between 2010 and 2050 to a total of 27.9 million (CEPAL 2007). The maintenance of the IUCN Red List status of 'Endangered' is justified according to the IUCN (2001) Red List criteria EN Bıa+b(ii,iii,v).

\section{Conservation implications and population monitoring}

The survival of the Azure-rumped Tanager depends on conservation of natural habitat and habitat restoration in and outside of protected areas. The necessity of conservation efforts in human-used landscape in Guatemala has been recognised during the identification of Important Bird Areas (Eisermann and Avendaño 2007b, 2009a,b), and it has also been recognised on a regional level in Mesoamerica (Harvey et al. 2008, Chazdon et al. 2009, Gardner et al. 2009). Because most of the tanager's range in Guatemala is covered with coffee plantations, these areas need to be considered in a conservation strategy. Coffee is being cultivated under a variety of management systems, ranging from intensive unshaded monoculture with an intensive use of agrochemicals, to rustic coffee plantations, which are cultivated under the shade of the natural forest. Between these extremes exist a variety of plantation types differentiated by species richness of shade trees and shade cover (Perfecto et al. 2005, López-Gómez et al. 2007, Hernández-Martínez et al. 2009). The conservation value of coffee plantations has been discussed since the 1990s (Komar 2006), and plantations with a diverse shade have been identified as the most valuable for biodiversity (Perfecto et al. 1996, Perfecto et al. 2003, Philpott et al. 2008). 
Most coffee plantations in the potential range of Azure-rumped Tanager in Guatemala are shaded monocultures. The use of forest edge and single trees within coffee plantations by foraging tanagers suggests that the area of suitable habitat could be augmented considerably by some shade alterations among plantations. The dense network of maintenance roads in coffee plantations could be used to establish lines of native trees, especially Ficus aurea, which would provide both food and nesting sites. In many plantations we saw Eucalyptus spp. trees planted along roads, so there would be little loss of cultivated area by replacing Eucalyptus or other non-native trees with Ficus aurea and other fruit trees. The creation of tree rows could even benefit the coffee plantations. Pollination experiments in Costa Rica showed that pollination of coffee blossoms is higher within a distance of $100 \mathrm{~m}$ from forest fragments and that forestbased pollinators increased coffee yield by $20 \%$ (Ricketts 2004, Ricketts et al. 2004). Increased shade and plant species richness in coffee plantations increases bird abundance (Philpott et al. 2008). Bird exclosure experiments in Chiapas showed that avian predation on Lepidoptera larvae was significantly higher in plantations with high floristic diversity (Perfecto et al. 2004). A similar test in Jamaican coffee plantations concluded that birds reduced significantly the infestation by coffee berry borers Hypothenemus hampei, Coleoptera: Scolytidae (Kellermann et al. 2008), which is also a common pest in Guatemalan coffee plantations. Johnson et al. (2009) pointed out that greater shade cover in a Jamaican coffee plantation increased predation on arthropods by birds, but it also increased fungal leaf damage on the coffee shrubs. Local environmental conditions vary widely, and the task is to find for each farm the balance between high coffee yield and satisfying support for biodiversity conservation. Incentives and certification programmes could play an important role in promoting these efforts. Habitat restoration measures should be accompanied by population monitoring of Azure-rumped Tanager. To continue monitor the distribution of the tanager we would appreciate receiving reports of observation sent by e-mail or submitted to eBird Guatemala at $<$ http://www.ebird. org/content/guatemala/>.

\section{Supplementary Material}

The online supplementary materials for this article can be found at journals.cambridge.org/bci

\section{Acknowledgements}

We appreciate the logistical support by the people of Los Tarrales Reserve. SA and KE are thankful to Andy Burge and Mónica Barrios for providing a temporary home at El Vesubio/Los Tarrales. We thank Olga Hazard and Jaime Freire (Los Andes), as well as Mark Brissani and Arnoldo Villagrán (Reserva San Jerónimo Miramar) for permitting us to work in their private reserves. We appreciate the field assistance and hospitality provided by Jamie Staples, Carlos Mazariegos, Marcelino Orozco and Saúl Sandoval (San Rafael Pie de la Cuesta), Mario Castillo and Fernando García (Las Nubes Reserve), the late Federico J. Fahsen (Pachuj Reserve), Olga Hazard, Jaime Freire, Jesús Lucas Yuxón, Juan Calvo Cortéz (Los Andes Reserve), people of Loma Linda, Mario Aguilar (Patrocinio Reserve). We thank Juan José Castillo Mont, Mario Veliz, and David Mendieta for the identification of plant specimens. We thank Kenset Rosales and Rafael Ávila of Consejo Nacional de Areas Protegidas (CONAP) for providing updated information on Guatemala's protected areas. We thank Sylke Frahnert and Pascal Eckhoff of the Museum für Naturkunde in Berlin, Germany, for their assistance during reviewing specimens in the ZMB. We appreciate the review of the manuscript by Joseph M. Wunderle and Phil Atkinson, and the revision of English usage by Peter Lowther through the Association of Field Ornithologists' programme of editorial assistance. Optics for the Tropics donated binoculars. This study was financially supported by Cayaya Birding, Los Tarrales Reserve, and PROEVAL RAXMU Bird Monitoring Program. 


\section{References}

Berg, C. C. (2007) Proposals for treating four species complexes in Ficus subgenus urostigma section americanae. Blumea 52: 295312.

BirdLife International (2008) Species fact sheet: Tangara cabanisi. <http://www. birdlife.org/datazone/species/index.html >; (downloaded 17 June 2008).

Blondel, J. and Cuvillier, R. (1977) Une méthode simple et rapide pour décrire les habitats d'oiseaux: le stratiscope. Oikos 29: 326-331.

Brodkorb, P. (1939) Rediscovery of Heleodytes chiapensis and Tangara cabanisi. Auk 56: 447-450.

Buckland, S. T., Anderson, D. R., Burnham, K. P., Laake, J. L., Borchers, D. L. and Thomas, L. (2001) Introduction to distance sampling: estimating abundance of biological populations. New York: Oxford University Press.

Cabanis, J. (1866) Über neue oder weniger bekannte exotische Vögel. J.für Ornithologie 14: 159-165.

CEPAL (2007) 2006 Anuario estadístico de América Latina y el Caribe / Statistical yearbook for Latin America and the Caribbean. Santiago, Chile: UN.

Chazdon, R. L., Harvey, C. A., Komar, O., Griffith, D. M., Ferguson, B. G., MartínezRamos, M., Morales, H., Nigh, R., SotoPinto, L., van Breugel, M. and Philpott, S. M. (2009) Beyond reserves: A research agenda for conserving biodiversity in human-modified tropical landscapes. Biotropica 41: 142-153.

Collar, N. J., Gonzaga, L. P., Krabbe, N., Madroño Nieto, A., Naranjo, L. G., Parker, III, T. A. and Wege, D. C. (1992) Threatened birds of the Americas: the ICBP/IUCN Red Data Book. Washington and London: Smithsonian Institution Press, and Cambridge, UK: International Council for Bird Preservation.

CONAP (2009) Lista de áreas protegidas inscritas en el SIGAP. Guatemala: Consejo Nacional de Áreas Protegidas (CONAP). [Institutional database, data provided in November 2009.]

Cooper, D. S. (2003) New distributional and ecological information on birds in southwestern Guatemala. Cotinga 19: 61-63.
Dietsch, T. V. (2000) Assessing the conservation value of shade-grown coffee: a biological perspective using Neotropical birds. Endangered Species Update 17: 122-124.

Eisermann, K. and Avendaño, C. (2006) Diversidad de aves en Guatemala, con una lista bibliográfica. Pp. 525-623 in E. Cano, ed. Biodiversidad de Guatemala, Vol. I Guatemala Ciudad, Guatemala: Universidad del Valle de Guatemala.

Eisermann, K. and Avendaño, C. (2007a) Lista comentada de las aves de Guatemala Annotated checklist of the birds of Guatemala. Barcelona, Spain: Lynx Edicions.

Eisermann, K. and Avendaño, C. (2007b) Áreas propuestas para la designación como IBA (Área importante para la conservación de aves) en Guatemala, con una priorización para la conservación adentro de las IBAs y una evaluación de las IBAs para aves migratorias Neárticas-Neotropicales. Informe final a BirdLife International, Quito, Ecuador. Sociedad Guatemalteca de Ornitología, Guatemala. <http://www.avesdeguatemala.org/ iba.htm >; (downloaded 25 November 2009).

Eisermann, K. and Avendaño, C. (2009a) Conservation priority-setting in Guatemala through the identification of Important Bird Areas. Proc. Fourth International Partners in Flight Conference, Tundra to Tropics: $315-$ 327.

Eisermann, K. and C. Avendaño (2009b) Guatemala. Pp. $235^{-242}$ in C. Devenish, D. F. Diaz Fernández, R. P. Clay, I. Davidson and I. Yépez Zabala, eds. Important Bird Areas Americas, priority sites for biodiversity conservation. Quito, Ecuador: Birdlife International. (BirdLife Conservation Series 16).

Eisermann, K., López, G., Berry, J., de León Lux, J. and Burge, A. (2011 in press) Vocalisations and juvenile plumage of Azurerumped Tanager Tangara cabanisi. Cotinga 33.

Engel, J. (1998) SsS. Eichenau, Germany: Rubisoft Software.

Gallini, S. (2009) Una historia ambiental del café en Guatemala: la Costa Cuca entre 1830 y 1902. Guatemala: AVANCSO.

Gardner, T. A., Barlow, J., Chazdon, R., Ewers, R. M., Harvey, C. A., Peres, C. A. 
and Sodhi, N. S. (2009) Prospects for tropical forest biodiversity in a humanmodified world. Ecol. Lett. 12: 561-582.

Godoy, J. C. (2008) Central America: Belize, Costa Rica, El Salvador, Guatemala, Honduras, Nicaragua, Panama. Pp. 199-207 in S. Chape, M. Spalding and M. Jenkins, eds. The world's protected areas: status, values, and prospects in the 21st century Berkley and Los Angeles, CA: University of California Press and UNEP World Conservation Monitoring Centre.

Harvey, C. A., Komar, O., Chazdon, R., Ferguson, B. G., Finegan, B., Griffith, D. M., Martínez-Ramos, M., Morales, H., Nigh, R., Soto-Pinto, L., van Breugel, M. and Wishnie, M. (2008) Integrating agricultural landscapes with biodiversity conservation in the Mesoamerican hotspot. Conserv. Biol. 22: 8-15.

Heath, M. and Long, A. (1991) Habitat, distribution and status of the Azurerumped Tanager Tangara cabanisi in Mexico. Bird Conserv. Int. 1: 223-254.

Hernández-Martínez, G., Manson, R. H. and Contreras Hernández, A. (2009) Quantitative classification of coffee agroecosystems spanning a range of production intensities in central Veracruz, Mexico. Ag. Ecosyst. Environ. 134: 89-98.

Hilty, S. L. and Simon, D. (1977) The Azurerumped Tanager in Mexico with comparative remarks on the Gray-and-gold Tanager. Auk 94: 605-606.

INEGI (2008) II conteo de población y vivienda 2005. México y sus municipios. México: Instituto Nacional de Estadística, Geografía e Información.

Isler, M. L. and Isler, P. R. (1987) The tanagers: natural history, distribution and identification. Washington, DC: Smithsonian Institution Press.

IUCN (1994) Guidelines for protected area management categories. Gland, Switzerland and Cambridge, UK: IUCN.

IUCN (2001) IUCN Red list categories and criteria: version 3.1. Gland, Switzerland and Cambridge, UK: IUCN Species Survival Commission.

Johnson, M. D., Levy, N. J., Kellermann, J. L. and Robinson, D. E. (2009) Effect of shade and bird exclusion on arthropods and leaf damage on coffee farms in Jamaica's Blue Mountains. Agroforest. Syst. 76: 139-148.

Jones, H. L. (2004) Spring migration, March though May 2004: Central America. N. Am. Birds 58: 446-448.

Kellermann, J. L., Johnson, M. D., Stercho, A. M. and Hackett, S. C. (2008) Ecological and economic services provided by birds on Jamaican Blue Mountain coffee farms. Conserv. Biol. 22: 1177-1185.

Komar, O. (2006) Ecology and conservation of birds in coffee plantations: a critical review. Bird Conserv. Int. 16: 1-23.

Krebs, C. J. 1999. Ecological methodology. and edition. Menlo Park, CA: Benjamin / Cummings.

López-Gómez, A. M., Williams-Linera, G. and Manson, R. H. (2007) Tree species diversity and vegetation structure in shade coffee farms in Veracruz, Mexico. Ag. Ecosyst. Environ. 124: 160-172.

MAGA (2002) Atlas de Guatemala. CD-Rom. Guatemala: Ministerio de Agricultura, Ganadería y Alimentación (MAGA).

MAGA (2006) Mapa de cobertura vegetal y uso de la tierra a escala 1:50,000 de la República de Guatemala, Año 2003 (Incluye 5 cultivos perennes actualizados al año 2005). Memoria técnica y descripción de resultados. Guatemala Ciudad, Guatemala: Ministerio de Agricultura Ganadería y Alimentación -MAGA- / Unidad de Planificación Geográfica y Gestión de Riesgo -UPGGR-.

MAGA (2010, in press) Obtención de imagenes digtales de la República de Guatemala del año 2006. Ministerio de Agricultura Ganadería y Alimentación (MAGA), Guatemala.

Parker, T. A. III, Hilty, S. and Robbins, M. (1976) Birds of the El Triunfo cloud forest, Mexico, with notes on the Horned Guan and other species. American Birds 30: 779782.

ParksWatch (2002) Park profile-Guatemala: Sierra de las Minas Biosphere Reserve. Guatemala: ParksWatch. <http://www. parkswatch.org >; (downloaded 21 November 2009).

ParksWatch (2005) Park profile-Guatemala: Laguna del Tigre National Park and Laguna del Tigre-Río Escondido Protected 
Biotope. Guatemala: ParksWatch. <http:// www.parkswatch.org >; (downloaded 21 November 2009).

Perfecto, I., Rice, R., Greenberg, R., Van der Voorts, M. (1996) Shade coffee: a disappearing refuge for diversity. BioScience 46 : 598-608.

Perfecto, I., Mas, A., Dietsch, T. and Vandermeer, J. (2003) Conservation of biodiversity in coffee agroecosystems: a tri-taxa comparison in southern Mexico. Biodivers. Conserv. 12: 1239-1252.

Perfecto, I., Vandermeer, J. H., López Bautista, G., Ibarra-Núñez, G., Greenberg, R., Bichier, P. and Langridge, S. (2004) Greater predation in shaded coffee farms: the role of resident Neotropical birds. Ecology 85: 2677-2681.

Perfecto, I., Vandermeer, J., Mas, A. and Soto Pinto, L. (2005) Biodiversity, yield, and shade coffee production. Ecol. Econ. 54: 435-446.

Philpott, S. M., Arendt, W. J., Armbrecht, I., Bichier, P., Dietsch, T. V., Gordon, C., Greenberg, R., Perfecto, I., Reynoso-Santos, R., Soto-Pinto, L., Tejeda-Cruz, C., Williams-Linera, G., Valenzuela, J. and Zolotoff, J. M. (2008) Biodiversity loss in Latin American coffee landscapes: review of the evidence on ants, birds, and trees. Conserv. Biol. 22: 1093-1105.

Richter, M. (2000) The ecological crisis in Chiapas: a case study from Central America. Mountain Res. Dev. 20: 332-339.

Ricker, W. E. (1984) Computation and uses of central trend lines. Can. J. Zool. 62: 18971905.
Ricketts, T. H. (2004) Tropical forest fragments enhance pollinator activity in nearby coffee crops. Conserv. Biol. 18: 1262-1271.

Ricketts, T. H., Daily, G. C., Ehrlich, P. R. and Michener, C. D. (2004) Economic value of tropical forest to coffee production. PNAS 101: 12579-12582.

Sclater, P. L. (1868) On a recently discovered tanager of the genus Calliste. Ibis 4 (series 2): $71-72$.

Tenez, D. (2005) Avifauna del volcán Lacandón, Quetzaltenango. Guatemala: Consejo Nacional de Áreas Protegidas. Unpublished report.

Thomas, L., Laake, J. L., Strindberg, S., Marques, F. F. C., Buckland, S. T., Borchers, D. L., Anderson, D. R., Burnham, K. P., Hedley, S. L., Pollard, J. H., Bishop, J. R. B. and Marques, T. A. (2006) Distance 5.0. Release 2. University of St. Andrews, UK: Research Unit for Wildlife Population Assessment.

Valdez, O. I., Marroquín, D. E., Orellana, R. E., Pérez, S. G., Sandoval, K. J., Villar, L., Godínez, C. V., Acevedo, M. E., Morales, J. E. and Reyes, L. E. (1999) Fauna en peligro de extinción de Guatemala: inventarios rápidos para la conservación. Informe final (noviembre). Guatemala: Centro de Estudios Conservacionistas, Univ. San Carlos. Unpublished report.

Vannini, J. P. (1989) Preliminary checklist to the birds of Finca el Faro, Quetzaltenango, Guatemala. Publicación Ocasional No. 2. Guatemala: Fundación Interamericana de Investigación Tropical.

KNUT EISERMANN, ${ }^{*}$ SUSANNE ARBEITER, CLAUDIA AVENDAÑO

PROEVAL RAXMU Bird Monitoring Program, Cobán, Alta Verapaz, Guatemala. clo P.O. Box 98 Periférico, Guatemala City, Guatemala.

SUSANNE ARBEITER

University of Applied Sciences Eberswalde, Friedrich-Ebert-Str. 28, 16225 Eberswalde, Germany.

GERARDO LÓPEZ AND JOSUÉ DE LEÓN LUX

Los Tarrales Reserve, Km 164.2 Ruta Nacional 11, Patulul, Suchitepéquez, Guatemala.

${ }^{*}$ Author for correspondence; e-mail: knut.eisermann@proeval-raxmu.org

Received 31 May 2010; revision accepted 26 October 2010; Published online 11 February 2011 